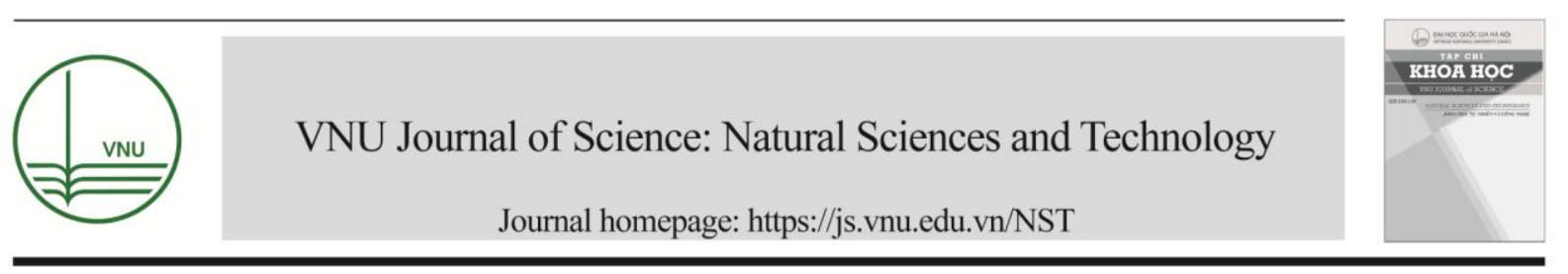

\title{
Study on Determination Method of Cyclic Siloxanes in Personal Care Products Collected from Hanoi, Vietnam
}

\author{
Tran Manh Tri*, Nguyen Le Hoai Linh \\ Faculty of Chemistry, VNU University of Science, 19 Le Thanh Tong, Hanoi, Vietnam \\ Received 19 March 2018 \\ Revised 06 June 2018; Accepted 06 June 2018
}

\begin{abstract}
Cyclic siloxanes are widely used in beauty products as softener and polisher. However, very few studies have reported the occurrence and amount of cyclic siloxanes in personal care products (PCPs).In this research, the analysis method of cyclic siloxanes including octamethylcyclotetrasiloxane (D4), decamethylcyclopentasiloxane (D5), and dodecamethylcyclohexasiloxane (D6) in PCPs was developed by using a gas chromatographymass spectrometry (GC/MS) system.The method detection limits and the method quantification limits of individual cyclic siloxanes were $0.7 \mathrm{ng} / \mathrm{g}$ and $2.0 \mathrm{ng} / \mathrm{g}$, respectively.Mean recoveries of surrogate compound(M4Q) and target compounds for the procedural blanks ranged from 88.5 to 94.9\%. The recoveries of M4Q for real samples ranged from 75.5 to $120 \%$ (RSD: $6.8 \%$ ). The optimal procedure was appliedto measure the amount of D4, D5, and D6 in several samples of PCPs including shampoos, hair gels, and shower gels collected from retail stores in Hanoi, Vietnam.Mean concentrations of D4, D5 and D6 in PCPs rangedof $1.25-22.4 \mu \mathrm{g} / \mathrm{g}, 2.73-$ $46.9 \mu \mathrm{g} / \mathrm{g}$, and $1.18-13.5 \mu \mathrm{g} / \mathrm{g}$, respectively.
\end{abstract}

Keywords: Siloxanes, PCPs, decamethylcyclopentasiloxane, M4Q, GC/MS.

\section{Introduction}

Siloxanes is a large group of organic compounds with high molecular weights (about hundreds to hundred thousand Dalton) in which chains of alternating silicon and oxygen atoms are linked toaliphatic chainsattached viasilicon atoms. Based on the structure of backbone, siloxanes are classified into two main groups:

\footnotetext{
*Corresponding author. Tel.: 84-976158181.

Email: manhtri0908@gmail.com

https://doi.org/10.25073/2588-1140/vnunst.4735
}

linear and cyclic siloxanes. Cyclic siloxanes with twomethyl groups regarded as aliphatic chains are also called cyclomethicones. Siloxanesare widely used in consumer products due to their discrete properties like low surface tension and smooth texture. A few studiesreported the occurrence of cyclic siloxanes in personal care products at high levels. Concentrations of octamethylcyclotetrasiloxane (D4) and decamethylcyclopentasiloxane(D5) in shampoos and hair conditioners were $72.9 \mu \mathrm{g} / \mathrm{g}$ and $1110 \mu \mathrm{g} / \mathrm{g}$, respectively [1]. 
Owing to their widespread uses in consumer products, there is a great potential for the increase in theconcentrations of siloxanes in indoor environments [2-4]. In recent studies, our research group reported the wide occurrence of cyclic and linear siloxanes in indoor environments from Vietnam. Total concentrations of 4 cyclic and 6 linear siloxanes in indoor air collected from several Northern cities in Vietnam ranged from 41.8 to 1950 $\mathrm{ng} / \mathrm{m}^{3}[5]$. The occurrence and distribution of 5 cyclicsiloxanes and 11 linear siloxanes were surveyed in 310 indoor dust samples collected from twelve countries, including Vietnam [3]. Further, siloxanes werealso found in sludge, sediment, and wastewater samples $[2,6,7]$.

In recent years, some cyclic siloxane compounds have been examined on their effects to laboratory animals [8-11]. A risk assessment conducted in Canada indicated that D5 met the criteria for environmental persistence [2]. The liver weight increases wasobserved in several toxicity studies on D5 inshortdurations and in the two-year chronic bioassay;D5 inhalation was concluded to causea small, but (borderline) statistically significant increase in the incidence of uterine adenocarcinoma at the highest exposure concentration of $160 \mathrm{ppm}$ [12]. Despite this, there is lack of information with regard to the sources of human exposure to siloxanes. In this study, we surveyed the method for determination of three cyclic siloxanes (D4, D5, and dodecamethylcyclohexasiloxane (D6)in PCPs. The optimal method was applied for detection of the levelsand distribution of cyclic siloxanes in some genres of PCP samples collected from Hanoi, Vietnam.

Table 1. Three cyclic siloxanes in this research

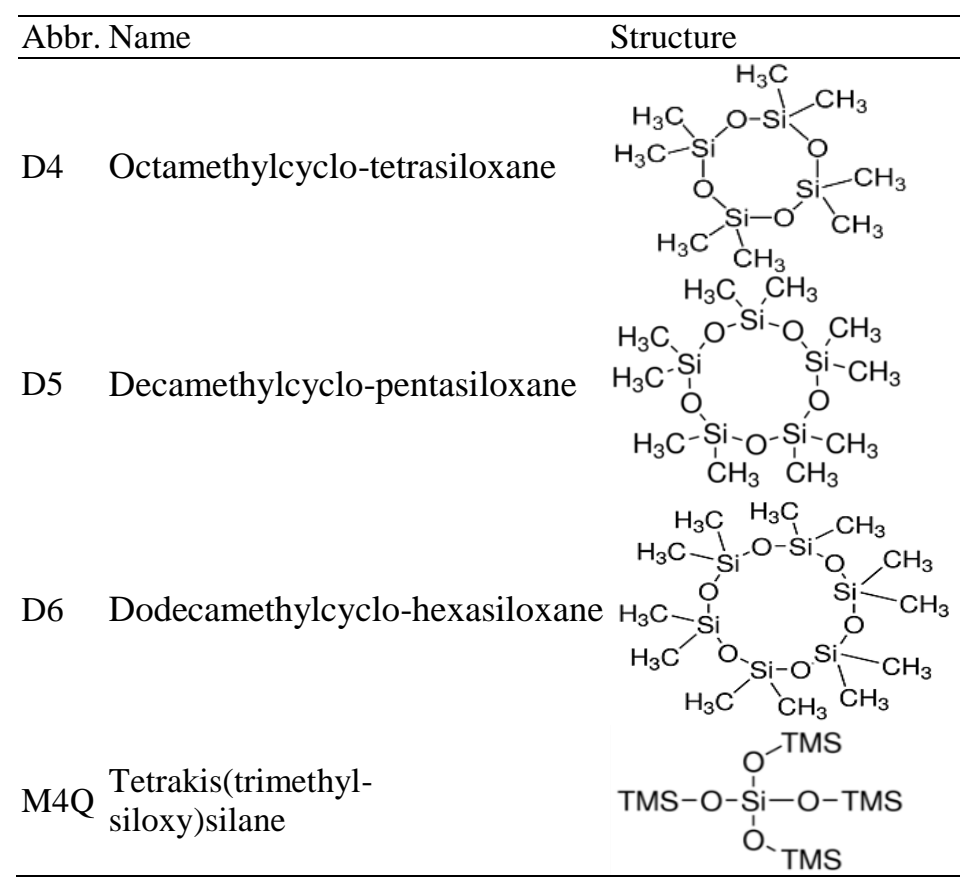

\section{Materials and methods}

\subsection{Solvents and standards}

$n$-hexane $(\geq 99.0 \%)$ for analysis was purchased from EMD Milipore Corporation
USA.Acetone, dichlomethane, and $n$-hexane for cleaning were purchased from Xilong Scientific Co., Ltd., China. D4, D5, D6and tetrakis(methylsiloxy)siloxane (M4Q) with thepurity of $97 \%$ were purchased from Sigma- 
Aldrich. M4Q was used as asurrogate standard. The target and surrogate compounds were dissolved in $n$-hexane.Standard mixture solutionswere prepared at different concentrations ranging from 3 to 1000 $\mathrm{ng} / \mathrm{mLin} n$-hexane.

\subsection{Sample collection}

Three product categories including shampoos, shower gels, and hair gelswere purchased from retail stores in Hanoi, Vietnam from August 2016 to March 2017. The sample selection was random with the goal of testing the optimized method. Samples werekept at room temperature until analysis (before expired date).

\subsection{Sample preparation}

As there is no siloxane-free sample, one five-gram sample was chosen to be treated as a blank. This liquid sample was shaken with 10 $\mathrm{ml}$ of $n$-hexane for $15 \mathrm{~min}$. The solvent layer was emitted out and the residue was kept and re-extracted four times as above to make sure that nearly all the cyclic siloxanes were no longer in the residue. The final remainder was acted as a blank.

The samples were pre-extracted similarlyas from following several reports $[1,7,13]$ with slight modification. About 0.1 to 0.3 grams of sample was weight and placed in a polypropylene tube. Then, 500 nanograms of internal standard (M4Q) were spiked. Samples were shakenfor $15 \mathrm{~min}$ and centrifugedat 3500 $\mathrm{rpm}$ for $5 \mathrm{~min}$. The solvent layer was transferred into a glass tube. Extraction was repeated twice more. Total extracted solution was concentrated to $1 \mathrm{~mL}$ by using a gentle nitrogen stream, followed by quantitatively transferringinto a GC vial.

\subsection{Instrumental analysis}

Analysis was performed on an Agilent Technologies 7890GC (for separation) interfaced with a 5977 mass spectrometer (MS) (for quantitation) (from Agilent Technologies,
Foster City, CA, USA). Separation of siloxanes was achieved by an HP-5MS capillary column ( $30 \mathrm{~m} \times 0.25 \mathrm{~mm}$ i.d $\times 0.25 \mu \mathrm{m}$ film thickness), from Agilent Technologies. The MS was operated in an electron impact selected ion monitoring mode (SIM). Ion fragment $\mathrm{m} / \mathrm{z} 281$ was monitored for D4, $\mathrm{m} / z 355$ for D5, and $\mathrm{m} / \mathrm{z}$ 341 for D6. Ion fragment $\mathrm{m} / z \quad 281$ was monitored for M4Q [4, 5].

Injector and detector temperature were set at $220^{\circ} \mathrm{C}$ and $280^{\circ} \mathrm{C}$, respectively. Two microlitersof sample was injected at the splitless mode. The program for the oven temperature is initially set at $40^{\circ} \mathrm{C}$ in $2.0 \mathrm{~min}$. Then, it gradually increased up to $220^{\circ} \mathrm{C}$ with the rate of $20^{\circ} \mathrm{C} / \mathrm{min}$ and $280^{\circ} \mathrm{C}$ (held in $10 \mathrm{~min}$ ) with a rate of $5^{\circ} \mathrm{C} / \mathrm{min}$. Finally, the oven temperature waskept at $300{ }^{\circ} \mathrm{C}$ in $5.0 \mathrm{~min}$ [3-5].

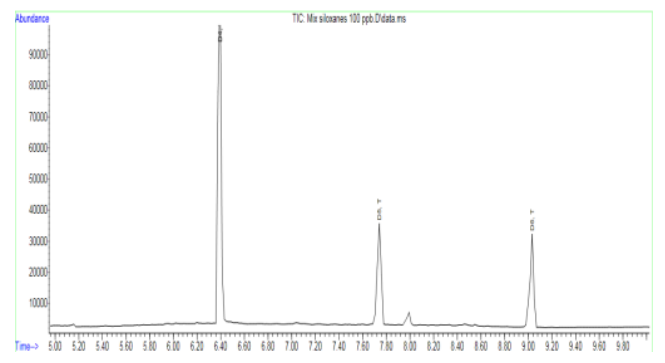

Fig. 1. Standard chromatograph of cyclic siloxanes

\section{Results and discussion}

\subsection{Blank procedure}

Contamination of siloxanes from materials and solvents in our laboratory has been examined in an earlier report [5]. Therefore, efforts to reduce background levels of siloxane contamination were made. All glassware were baked at $450^{\circ} \mathrm{C}$ for $20 \mathrm{~h}$ and placed in an oven at $100^{\circ} \mathrm{C}$ until use. The GC vials were capped with aluminum foil, and the solvents were dispensed directly from new glass bottles (i.e., a solvent-bottle that was kept open for more than a day was not used). Prior to instrumental analysis, $n$-hexane was injected into the GCMS until the background levels of siloxanes became stable. $n$-hexane also was injected 
before every sample as a check for background contamination and carry-over $[3,5]$.

\subsection{Parameters of method}

\section{* The method detection limit (MDL) and the method quantification limit (MQL)}

In this research, the instrument detection limits (IDLs) and instrument quantification limits (IQLs) on GC/MS system were respectively 5 and 15 picograms for individual cyclic siloxanes. The MDL and MQL were calculated based on the IDLs and IQLs, sample volume (5 grams), recovery (88.5-94.9\%), concentrated solution volume $(1 \mathrm{~mL})$ and injected volume $(2 \mu \mathrm{L})$. The MDL and MQL of individual cyclic siloxanes were 0.7 and 2.0 ng/g, respectively. In general, the MDL and MQL values met the requirement of detection method for cyclic siloxanes in PCPs.

\section{* The recoveries and repetitions}

Five hundred nano-grams of individual cyclic siloxanes and M4Q were spiked into blank samples. The analysis was done according to theprocedure. The recoveries of target compounds were calculated based on the initial spiked amount and the determined amount in spiked samples. The mean recovery values of cyclic siloxanes and surrogate compound ranged from 88.5 to $94.9 \%$. The relative standard deviation values ranged from 7.21 to $13.4 \%$ (Table 2).

Table 2. The recoveries of cyclic siloxanes and M4Q (\%)

\begin{tabular}{lllll}
\hline Times & D4 & D5 & D6 & M4Q \\
\hline $1^{\text {st }}$ & 78.4 & 95.5 & 89.3 & 91.1 \\
$2^{\text {nd }}$ & 83.6 & 110 & 106 & 95.5 \\
$3^{\text {th }}$ & 98.5 & 75.9 & 72.6 & 82.4 \\
$4^{\text {th }}$ & 75.2 & 99.1 & 76.6 & 101 \\
$5^{\text {th }}$ & 97.4 & 97.3 & 104 & 105 \\
$6^{\text {th }}$ & 102 & 83.5 & 98.0 & 93.7 \\
$7^{\text {th }}$ & 84.1 & 87.9 & 81.5 & 95.4 \\
Mean & 88.5 & 92.7 & 89.7 & 94.9 \\
RSD & 10.7 & 11.2 & 13.4 & 7.21 \\
\hline
\end{tabular}

Five hundred nano-grams of M4Q were also spiked into every sample. The recoveries of
M4Q for real samples ranged from 75.5 to 120\% (RSD: 6.8\%). Concentrations of target compounds in PCP samples were calculated based on the recoveries of surrogate compound.

\subsection{Concentrations of cyclic siloxanes in personal care products}

In this work, three typical cyclic siloxanes were found in all personal care product samples collected in Hanoi, Vietnam. The total concentrations of cyclic siloxanes in PCPs ranged from 2.87 to $122 \mu \mathrm{g} / \mathrm{g}$.Among studied cyclic siloxanes, D5 was found at the highest levels in hair gels. Concentrationsof D5 in hair gels ranged from 6.92 to $104 \mu \mathrm{g} / \mathrm{g}$ (mean: $46.9 \mu \mathrm{g} / \mathrm{g})$. D4 and D6 were also found at the high levels in hair gels with the rangeof 5.92$60 \mu \mathrm{g} / \mathrm{g}$ (mean: $22.4 \mu \mathrm{g} / \mathrm{g}$ ) and $7.92-20.4 \mu \mathrm{g} / \mathrm{g}$ (mean: $13.5 \mu \mathrm{g} / \mathrm{g}$ ), respectively. Meanwhile, D4, D5, and D6 were shown at the low levels in shower gels (Fig. 2).

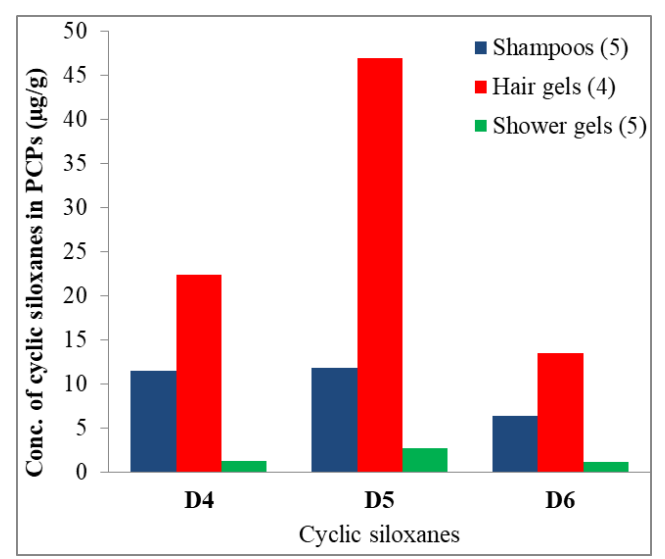

Fig. 2. Concentrations of cyclic siloxanes in three kinds of PCPs collected from Hanoi, Vietnam. Values in parentheses(after kinds of samples) refer to the number of samples.

The results in this research are compared with an earlier report. Mean concentrations of D4, D5, and D6 in hair care products collected from China were respectively $13.8 ; 54.2$; and $16.7 \mu \mathrm{g} / \mathrm{g}$ [1]. However, previous studies reported higher concentrations of cyclic 
siloxanes in PCPs in comparison with this research. Mean concentrations of D4 and D5 in hair gels collected from Canada were 70 and $100 \mu \mathrm{g} / \mathrm{g}$, respectively [6]. Further, very high concentration of D5 was measured in hair care products collected from the United State and Japan, up to $5890 \mu \mathrm{g} / \mathrm{g}[13]$.

\subsection{Distribution of cyclic siloxanes in PCPs}

The total mean concentration of three cyclic siloxanes hair gels, shampoos, and shower gels were $82.9,29.6$, and $5.16 \mu \mathrm{g} / \mathrm{g}$, respectively. The results showed that the total levels of cyclic siloxanes in PCPs collected from Vietnam were lower than the values in earlier reports $[6,13]$. However, these results from this study also showed that the amounts of total cyclic siloxanes in personal care products ranged up to $0.0005-0.008 \%$ in weights. This may explained the wide occurrence of siloxanes in indoor environments in Vietnam $[3,5]$.

In three kinds of PCPs, D5 was at the highest abundant. Among three cyclic siloxanes, distribution percentage of D5 in hair gels, shower gels and shampoos were 56.6; 53.0; and 40.0\%, respectively (Fig. 3). Generally, the results in this research are similarly with previous reports with high abundant and levels of D5 in PCPs $[1,7]$.

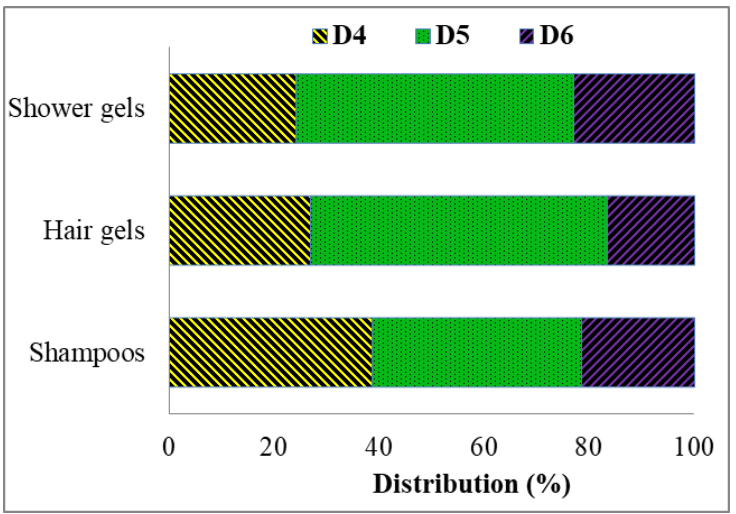

Fig. 3. Distribution of three cyclic siloxanes in PCPs.

\section{Conclusions}

This is thefirst study reported the determination method of cyclic siloxanes in personal care products in Vietnam. The chromatographic analysis conditions and the effective values of the method weresurveyed and optimized. The optimal method was applied for quantification of three common cyclic siloxanes in three kinds of PCPs collected from Hanoi, Vietnam.

\section{Referrences}

[1] Lu, Y., Yuan, T., Wang, W., Kannan, K., 2011. Concentration and assessment of exposure to siloxanes and synthetic musks in personal care products from China.Environ. Pollut. 159, 3522-3528.

[2] Environment Canada, Health Canada, 2011. Screening assessment for the challenge: Siloxanes and silicones, di-Me, hydrogen-terminated: Chemical abstracts service registry number 70900-21-9. Government of Canada. Available: http://www.ec.gc.ca/eseees/default.asp?lang=En\&n=4996570F-1\#top.

[3] Tran, M.T., Abualnaja, O.K., Asimakopoulos, G.A., Covaci, A., Gevao, B., Johnson-Restrepo, B., Kumosani, A.T., Malarvannan, G., Minh, B.T., Moon, B.H., Nakata, H., Sinha, K.R., Kannan, K., 2015. A survey of cyclic and linear siloxanes in indoor dust and their implications for human exposures in twelve countries.Environ. Int. 78, 39-44.

[4] Tran, M.T., Kannan, K., 2015. Occurrence of cyclic and linear siloxanes in indoor air from Albany, New York, USA, and its implications for inhalation exposure.Sci. Total Environ. 511, 138-144.

[5] Tran, M.T., Le, T.H., Vu, D.N., Dang, M.H.G., Minh, B.T., Kannan, K. 2017. Cyclic and linear siloxanes in indoor air from several northern cities in Vietnam: Levels, spatial distribution and human exposure. Chemosphere 184, 1117-1124.

[6] Bletsou, A.A., Asimakopoulos, A.G., Stasinakis, A.S., Thomaidis, N.S., Kannan, K., 2013. Mass loading and fate of linear and cyclic siloxanes in a wastewater treatment plant in Greece. Environ. Sci. Technol. 47, 1824-1832.

[7] Wang, R., Moody, R.P., Koniecki, D., Zhu, J., 2009. Low molecular weight cyclic volatile 
methylsiloxanes in cosmetic products sold on Canada: Implication for dermal exposure. Environ. Int. 35, 900-904.

[8] Burn-Naas, L.A., Meeks, R.G., Kolesar, G.B., Mast, R.W., Elwell, M.R., Hardisty, J.F., Thevenaz, P., 2002. Inhalation toxicology of octamethylcyclotetrasiloxane (D4) following a 3 month nose-only exposure in Fischer 344 rats.Int. Toxicol. 21, 39-53.

[9] He, B., Rhoders-Brower, S., Miller, M.R., Munson, A.E., Germolec, D.R., Walker, V.R., Korach, K.S., Meade, B.J., 2003. Octamethylcyclotetrasiloxane exhibits estrogenic activity in mice via ER $\alpha$. Toxicol. App. Pharm. 192, 254-261.

[10] Meeks, R.G., Stump, D.G., Siddiqui, W.H., Holson, J.F., Plotzke, K.P., Reynolds, V.L., 2007. An inhalation reproductive toxicity study of octamethylcyclotetrasiloxane $\left(\mathrm{D}_{4}\right)$ in female rats using multiple and single day exposure regimens.Reprod. Toxicol. 23, 192-201.

[11] Siddiqui, W.H., Stump, D.G., Plotzke, K.P., Holson, J.F., Meeks, R.G., 2007. A twogeneration reproductive toxicity study of octamethylcyclotetrasiloxane $\left(D_{4}\right)$ in rats exposed by whole-body vapor inhalation.Reprod. Toxicol. 23, 202-215.

[12] Dekant, W., Klaunig, E.J., 2016. Toxicology of decamethylcyclopentasiloxane (D5).Regul.Toxicol.Pharmacol.74, S67-S76.

[13] Horii, Y., Kannan, K., 2008. Survey of organosiloxane compounds, including cyclic and linear siloxanes, in personal-care and household products.Arch. Environ. Contam.Toxicol. 55, 701-710.

\title{
Nghiên cứu phương pháp xác định siloxane mạch vòng trong sản phẩm chăm sóc cá nhân thu mua tại Hà Nội, Việt Nam
}

\author{
Trần Mạnh Trí, Nguyễn Lê Hoài Linh \\ Khoa Hóa học, Truờng Đại học Khoa học Tự nhiên, ĐHQGHN, 19 Lê Thánh Tông, Hà Nội, Việt Nam
}

Tóm tắt: Các siloxane mạch vòng được sử dụng rộng rãi trong các sản phẩm làm đẹp như là tác nhân để làm mềm và mượt.Tuy nhiên, rất ít nghiên cứu chỉ ra sự xuất hiện cũng như hàm lượng của các chất này trong các sản phẩm chăm sóc cá nhân (PCPs).Trong nghiên cứu này, phương pháp phân tích các siloxane mạch vòng bao gồm including octamethylcyclotetrasiloxane (D4), decamethylcyclopentasiloxane (D5) và dodecamethylcyclohexasiloxane (D6) trong PCPs đã được phát triển trên thiết bị sắc kí khí ghép nối khối phổ (GC/MS).Giới hạn phát hiện và giới hạn định lượng tương ứng là $0.7 \mathrm{ng} / \mathrm{g}$ và $2.0 \mathrm{ng} / \mathrm{g}$ đối với tất cả các siloxane mạch vòng trong nghiên cứu. Độ thu hồi trung bình của chất đồng hành $(\mathrm{M} 4 \mathrm{Q})$ và của các siloxane mạch vòng trong mẫu trắng nằm trong khoảng 88.5 đến $94.9 \%$. Độ thu hồi của chất đồng hành $\mathrm{M} 4 \mathrm{Q}$ tiêm vàotrong các mẫu phân tích nằm trong khoảng 75.5 đến $120 \%$ (RSD: 6.8\%). Quy trình tối ưu đã được áp dụng để xác định hàm lượng của $\mathrm{D} 4, \mathrm{D} 5$ và $\mathrm{D} 6$ trong một số mẫu sản phẩm chăm sóc cá nhân bao gồm dầu gội đầu, keo xịt tóc và sữa tắm thu mua tại các siêu thị ở Hà Nội, Việt Nam. Nồng độ trung bình của D4, D5 và D6 trong PCPs nằm trong khoảng $1.25-22.4 \mu \mathrm{g} / \mathrm{g}, 2.73-46.9 \mu \mathrm{g} / \mathrm{g}$ và $1.18-13.5 \mu \mathrm{g} / \mathrm{g}$ tương ứng.

Tù khóa: Siloxanes, PCPs, decamethylcyclopentasiloxane, M4Q, GC/MS. 